BIOTROPIA NO. 25, $2005: 1-10$

\title{
ISOLATION AND CHARACTERIZATION OF MANNANOLYTIC THERMOPHILIC BACTERIA FROM PALM OIL SHELL AND THEIR MANNANASE ENZYME PRODUCTION PROPERTIES
}

\author{
SUMARDI $^{1}$, ANTONIUS SUWANTO ${ }^{2}$, MAGGY THENAWIDJAJA ${ }^{3}$, and \\ TRESNAWATI PURWADARIA ${ }^{4}$ \\ ${ }^{1}$ Department of Biology, Faculty of Science and Mathematics, University of Lampung, \\ Jl. S. Brojonegoro No. 1, Bandar Lampung 35145, Indonesia \\ ${ }^{2}$ Department of Biology, Faculty of Science and Mathematics, Bogor Agricultural University, \\ Jl. Raya Pajajaran, Bogor 16144, Indonesia \\ ${ }^{3}$ Department of Food Science and Human Nutrition, Bogor Agricultural University, \\ Darmaga, 16680, Bogor, Indonesia \\ ${ }^{4}$ Indonesian Research Institute for Animal Production, P.O. Box 221, Bogor 16002, Indonesia
}

\begin{abstract}
A mannanolytic thermophilic bacterium (L-07) was isolated from palm oil shell after 2 days of enrichment in liquid medium supplemented with $1 \%$ palm kernel meal as mannan source. Sequence analysis of 16S-rRNA indicated that L-07 was similar (98\%) to Geobacillus stearothermophilus, a species of thermophilic aerobic bacteria. We found that G. stearothermophilus L-07 produced extracellular $\beta$-1,4-mannanases, but no $\beta$-manosidase and $\alpha$-galactosidase activities. The growth of L-07 reached its maximum $\left(3.0 \times 10^{6} \mathrm{cell} / \mathrm{ml}\right)$ at $12-20$ hours, while the highest $\beta$-mannanase activity $(0.52$ $\mathrm{U} / \mathrm{ml}$ ) was observed in culture medium after 36 hours of cultivation at $60^{\circ} \mathrm{C}$. The medium containing locust bean gum was the best for producing extracellular $\beta$-1,4-mannanases compared with kolang kaling, konjak, and palm kernel meal. SDS-PAGE and zymogram analysis demonstrated that crude mannanase complex of L-07 from locust bean gum containing medium comprised three active bands with molecular weight of 85,73 and $50 \mathrm{kDa}$.
\end{abstract}

Keywords : Extracellular enzyme/mannanase/Geobacillus stearothermophilus

\section{INTRODUCTION}

Hemicelluloses are the second most abundant polysaccharide in nature after cellulose. The major constituents of hemicellulose are the hetero-1,4- $\beta$-D-xylans and hetero-1,4- $\beta$-D-mannans (galactoglucomannan, galactomannan, and glucomannan). The heteroxylans are found mainly in grasses, cereals, and hardwoods (angiosperms). The mannans are more abundant in copra, palm, coffee, and locust bean endosperms (Araujo and Ward 1990).

Mannanolytic microbes were found in soil, compost, and animal rumen (Zakaria et al. 1998). Biodegradation of $\beta$-mannans is caused by $\beta$-mannanase (1,4- $\beta$-D mannan manohidrolase [EC 3.2.1.78]) produced from bacteria and fungi. The enzyme hydrolyses the $\beta-(1,4)$ - linkages in backbone of mannan polymer,

${ }^{*}$ Corresponding author : asuwanto@indo.net.id 
producing short chain mannoligosaccharides. Then, these compounds can be further degraded by the action of $\beta$-mannosidase ( $\beta$-D-mannosidase [EC 3.2.1.25]) and a $\alpha$ galactosidase (EC 3.2.1.22) (Duffaud et al. 1997). Mannan degradation from glucomannan and galactomannan produces manno-oligosaccharide, mannobiose, and mannose. Mannan-degrading enzymes can be used for numerous applications in food, feed, pulp, and paper industries.

In the palm oil factory, during the composting process of palm shells containing hemicellulose the temperature rises to $65^{\circ} \mathrm{C}$. At such temperature, many thermophilic bacteria are able to develop special properties to survive and prosper in the habitat. The purposes of this study were to isolate the mannanolytic thermophilic bacterium from palm shells, a solid waste of palm oil factory in Lampung, and to study its B-mannanase production.

\section{MATERIALS AND METHODS}

\section{Materials}

Palm shell as source of thermophilic bacteria was obtained from palm oil industry in Natar, Lampung at $65^{\circ} \mathrm{C}$. Locust bean gum (galactomannan) was obtained from Sigma Chemical Company. Other chemicals were analytical grade from Merck Industry.

\section{Isolation of Thermophilic Mannanolytic Strains}

One milligram of palm shells was enriched in a medium containing $0.2 \%$ yeast extract; $0.2 \%$ trypton, $1.0 \%$ palm kernel meal, $0.02 \% \mathrm{MgSO}_{4}, 0.14 \% \mathrm{KH}_{2} \mathrm{PO}_{4}$, and $0.1 \%\left(\mathrm{NH}_{4}\right)_{2} \mathrm{SO}_{4}$ at $70^{\circ} \mathrm{C}$ for two days with agitation $(120 \mathrm{rpm})$. One hundred microliters of each enrichment culture was spread aerobically on the same medium onto agar plates containing $0.3 \%$ locust bean gum instead of palm kernel meal. Thermophilic mannanolytic isolates showed a clear zone around the colony after staining with a solution of $0.1 \%$ congo red for 15 minutes and destaining through repeated washing with $1 \mathrm{M} \mathrm{NaCl}$.

\section{Characterization and Identification of Isolate}

Morphological properties and taxonomic characteristics of the best isolate were studied according to the methods as described in "Bergey's Manual of Systematic Bacteriology" (Holt et al. 1994).

Identification of the isolate was determined through 16S rRNA sequence analysis. Genomic DNA extraction was performed using the CTAB method. PCRmediated amplification of the 16S rRNA was performed as described by Marchesi et al. (1998) employing GeneAmp PCR system 2400 (Perkin Elmer). PCR product was purified and sequenced. Cluster analysis was conducted according to a program 
provided by European Bioinformatics Institute (http://www. Ebi.ac.uk) and phylogenetic tree was constructed using Treecon software (Peer and Watcher 1993).

\section{Extracellular Enzyme Production}

The best bacterial isolate was grown in the medium for mannanase production which contained $0.35 \%$ yeast extract, $0.35 \%$ trypton, $0.035 \% \mathrm{MgSO}_{4}, 0.245 \%$ $\mathrm{KH}_{2} \mathrm{PO}_{4}, 0.175 \%\left(\mathrm{NH}_{4}\right)_{2} \mathrm{SO}_{4}, 0.2 \% \mathrm{NaCl}$, and $0.65 \%$ locust bean gum ( $\mathrm{pH} 7.0$ ). Locust bean gum was replaced with other carbon sources (kolang kaling, konjak, palm kernel meal) when the effect of carbon sources on the enzyme production was examined. A $250-\mathrm{ml}$ flask containing $50 \mathrm{ml}$ of the medium was inoculated with a loopful of cells taken from a stock slant and was precultured at $60^{\circ} \mathrm{C}$ on shaker $(120$ $\mathrm{rpm}$ ) for 6-8 hours. The same volume of medium and flasks for enzyme production were inoculated with $2 \mathrm{ml}$ of this culture and cultivated at $60^{\circ} \mathrm{C}$ for $48 \mathrm{~h}$. Aliquots of the culture medium were sampled at $4 \mathrm{~h}$ intervals to determine $\beta$-mannanase activity and viable bacterium number.

\section{Intracellular Enzyme Extraction}

G. stearothermophilus L-07 cells were concentrated from $50 \mathrm{ml}$ liquid medium by centrifugation at $3,200 \times \mathrm{g}$ for $10 \mathrm{~min}$. at $4^{\circ} \mathrm{C}$. The cell pellets were resuspended in $1 \mathrm{ml}$ of ice-cold condition containing $50 \mathrm{mM}$ Phosphat buffer. The cell lysis process used sonication with a Soniprep 150 (USA). The sonicator was set to 16 micron amplitude for 5 minutes. Intracellular enzymes were detected specifically $\beta$ mannanase, $\beta$-mannosidase, and $\alpha$-galactosidase.

\section{Enzyme Assay}

$\beta$-mannosidase and $\alpha$-galactosidase activities were determined by monitoring the release of $p$-nitrophenol from $p$-nirophenyl B-D-mannopyranoside or $p$ nitrophenyl $\alpha$-galactophyranoside (Sigma Chemical Co., USA), respectively. For each assay, $0.9 \mathrm{ml}$ aliquots of $1 \mathrm{mM}$ substrate in $50 \mathrm{mM}$ sodium phosphate buffer ( $\mathrm{pH} 7.0$ ) and $0.1 \mathrm{ml}$ of enzyme were mixed and incubated at $80^{\circ} \mathrm{C}$ for 30 minutes and the reaction stopped by the addition of $0.1 \mathrm{ml}$ solution of $0.4 \mathrm{M} \mathrm{Na}_{2} \mathrm{CO}_{3}$. The release of $p$-nitrophenyl (PNP) was measured spectrophotometrically by monitoring the changes in absorbance at $405 \mathrm{~nm}$. Control was prepared with the addition of enzyme after $\mathrm{Na}_{2} \mathrm{CO}_{3}$ solution. One unit of $\beta$-mannosidase or $\alpha$-galactosidase activity was defined as the amount of enzyme releasing $1 \mu \mathrm{mol}$ PNP per min. under the specified assay condition.

$\beta$-mannanase activity was determined by monitoring the release of reducing sugars. The reaction mixture, containing $0.5 \%$ locust bean gum, $50 \mathrm{mM}$ sodium phosphate buffer ( $\mathrm{pH} 7.0$ ), suitably diluted enzyme solution in a total volume of 1 $\mathrm{ml}$, was incubated at $80^{\circ} \mathrm{C}$ for 30 minutes. The reducing sugar content was determined by dinitrosalisylic acid method. One unit of enzyme was defined as the 
amount of enzyme producing $1 \mu \mathrm{mol}$ of mannose per minute under the given assay condition.

\section{Sodium Dodecyl Sulfate-Polyacrylamide Gel Electrophoresis (SDS-PAGE) and Zymogram}

SDS-PAGE was performed in $8 \%$ polyacrylamide gels. Protein bands were visualized after staining with silver nitrate. Zymogram was prepared using $0.1 \%$ locust bean gum co-polymerized with polyacrylamide. After separation, SDS was removed by method of Spindler and Rapp (1997). Then, the gel was equilibrated through several washings and finally immersed in $50 \mathrm{mM}$ sodium acetate buffer $(\mathrm{pH}$ 6.0 ), followed by incubation at $65^{\circ} \mathrm{C}$ for 35 minutes, staining with $0.1 \%$ congo red for 15 minutes, and destaining in $1 \mathrm{M} \mathrm{NaCl}$.

\section{RESULTS AND DISCUSSION}

We found 15 bacterial isolates from palm oil shell. Then the bacteria were screened for mannanase activity on selected medium agar plate containing locust bean gum at $70^{\circ} \mathrm{C}$ with $\mathrm{pH} 7.0$. Only isolate L-07 showed mannanase activity. The isolate L-07 could grow at $55-70^{\circ} \mathrm{C}$ and showed mannanase activity as high as 3.1 $\mathrm{U} / \mathrm{mg}$.

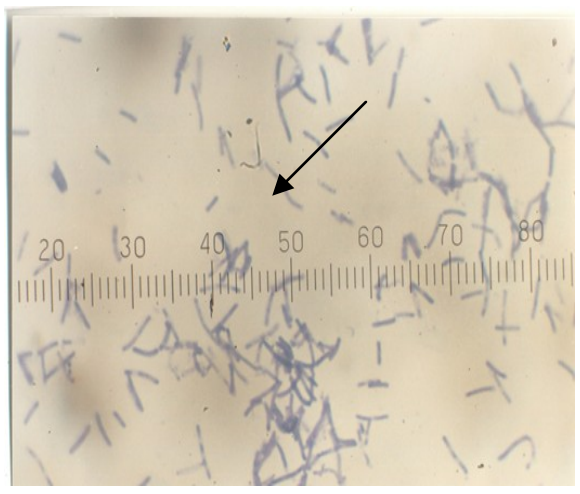

a.

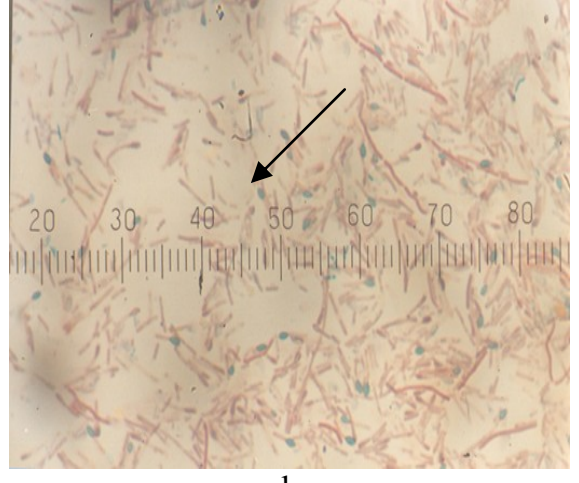

b.

Figure 1. Bacterial isolate L-07. a. Gram-positive rod-shaped cells were cultured at $65^{\circ} \mathrm{C}$ for 1 day. b. Cells produced endospore in terminal position after 5 days of incubation.

Table 1 shows the morphological and physiological characteristics of L-07. L07 was gram-positive (Figure 1.a), aerobic, catalase-positive, and endosporeforming bacterium (Figure 1.b). It was non-motile and rod-shaped (1-1.2 x 5-5.7 $\mu \mathrm{m})$. Based on these characteristics L-07 belonged to the genus Bacillus. 
Isolation and characterization of mannanolytic thermophilic bacteria - Sumardi et al.

Table 1. Morphological and physiological characteristics of L07 isolate

\begin{tabular}{|c|c|}
\hline Characteristics & Strain L-07 \\
\hline Shape & rod \\
\hline Endospora shape & oval/cylindrical \\
\hline Endospora position & terminal \\
\hline Gram stain & positive \\
\hline Catalase & positive \\
\hline Motility & negative \\
\hline Growth at $37^{\circ} \mathrm{C}$ & negative \\
\hline Growth & $55-75^{\circ} \mathrm{C}$ \\
\hline Optimum growth temperature & $60-70^{\circ} \mathrm{C}$ \\
\hline Cell size $(\mu \mathrm{m})$ & $1,2 \times 5,7$ \\
\hline Nitrate reduction & positive \\
\hline Indole production & negative \\
\hline Urease & positive \\
\hline Voges proskauer test & negative \\
\hline \multicolumn{2}{|l|}{ Utilization as sole carbon source of } \\
\hline Glucose & positive \\
\hline Mannose & positive \\
\hline Xylose & positive \\
\hline Sucrose & positive \\
\hline Arabinose & positive \\
\hline Ramnose & negative \\
\hline Citrate & negative \\
\hline Lactose & negative \\
\hline Mannitol & negative \\
\hline Sorbitol & negative \\
\hline Adonitol & negative \\
\hline Rafinose & negative \\
\hline Hydrolysis of mannan & positive \\
\hline Hydrolysis of carboxymethyl cellulose & positive \\
\hline Hydrolysis of starch & negative \\
\hline Hydrolysis of xylan & negative \\
\hline
\end{tabular}

Then, the total sequence of 1315 bp of $16 \mathrm{~S}$ rRNA gene of L-07 showed $98 \%$ similarity to that of Geobacillus stearothermophilus. The constructed phylogenetic tree for L-07 is shown in Figure 2.

G. stearothermophilus (formerly Bacillus stearothermophilus) was a highly resistant thermophilic organism. Major strains of the genus Geobacillus live in geothermal areas, such as the oil field subsurface and hydrothermal vents (Nazina et al. 2001; and Euzeby 2005). At this time, no study has reported on the presence of mannanolytic thermophilic bacteria from palm shell. As comparison Aurora et al (2003) showed that Bacillus pumilus DYP2, a mannanolytic mesophilic bacteria, was isolated from West Sumatra copra soil sample, Indonesia. Another bacterium, $B$. stearothermophilus ATCC 12016 has been previously reported to produce thermostable $\beta$-mannanase (Ethier et al. 1998). 


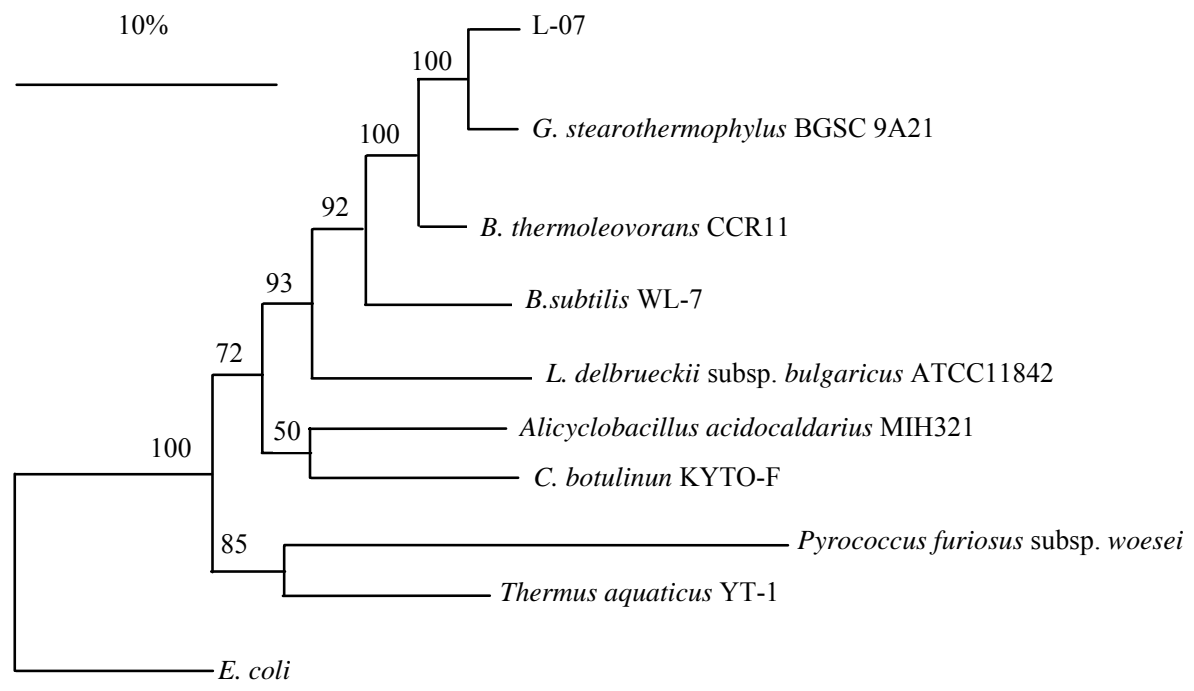

Figure 2. Phylogenetic tree construction for L-07 isolate. Bootstrap values are shown at each node tree.

When G. stearothermophilus L-07 produced thermophilic mannanase, the enzyme was observed primarily in culture media. The other two enzymes, $\alpha-1,6$ galactosidase and $\beta-1,4$ mannosidase were not detected in extracellular enzyme preparation (Table 2). These enzymes might act to provide simple sugar to Geobacillus stearothermophilus L-07 growing on locust bean gum as base media. Regarding the cellular localization of these three activities, we speculate that the mannan backbone was cleaved by endo-acting $\beta-1,4$ mannanase prior to the transport of smaller galactomannans to the site of the other two enzymes. The other two enzymes, exo-acting $\alpha-1,6$ galactosidase and $\beta-1,4$ mannosidase, are found in the cell membrane. As comparison, Duffaud et al. (1997) showed that extracellular $\beta-1,4$ mannanase of Thermotoga neopalitana 5068 was sevenfold greater than the cell extract. The other two enzymes, $\alpha-1,6$ galactosidase and $\beta-1,4$ mannosidase were found in the cell the extract.

Table 2. The specific activity of extracellular and intracellular mannanolytic enzymes from Geobacillus stearothermophilus L-07 cultured at $60^{\circ} \mathrm{C}$ for 36 hours

\begin{tabular}{llll}
\hline \hline \multirow{2}{*}{ No } & \multicolumn{1}{c}{$\begin{array}{c}\text { Kind of } \\
\text { enzyme }\end{array}$} & \multicolumn{2}{c}{ Specific activity $(\mathrm{U} / \mathrm{mg})$} \\
\cline { 3 - 4 } & & Intracellular & Extracellular \\
\hline 1 & $\beta-1,4$-mananase & $0.02 \pm 0.002$ & $3.10 \pm 0.050$ \\
2 & $\beta-1,4$-manosidase & $0.03 \pm 0.003$ & $0.00 \pm 0.000$ \\
3 & $\alpha-1,6$-galactosidase & $24.1 \pm 0.060$ & $0.00 \pm 0.000$ \\
\hline
\end{tabular}


We also observed the growth and extracellular $\beta$-mannanase activity of $G$. stearothermophilus L-07 as shown in Figure 3. After 12-20 hours of observation strain L-07 reached its maximum growth, while the highest $\beta-1,4$-mannanase activity was found in culture medium after 36 hours of cultivation. $\beta-1,4$-mannanase may be associated with the cell membrane. So, after G. stearothermophilus cells died $\beta$-1,4-mannanase leaked out from membrane and increased the activities. Besides for mannan degradation to produce manno-oligosaccharide, this thermostable enzyme can be used in the bleaching process (Ethier et al. 1998).

The other $\beta$-mannanase from Bacillus sp. was active at $70^{\circ} \mathrm{C}$. The enzyme was stable when incubated for $1 \mathrm{~h}$ at $\leq 60^{\circ} \mathrm{C}$ (Ooi and Kikuchi 1995). While the $\beta$ mannanase from Rhodothermus marinus retained $87 \%$ of its initial activity after $1 \mathrm{~h}$ at $90^{\circ} \mathrm{C}$ (Politz et al. 2000).

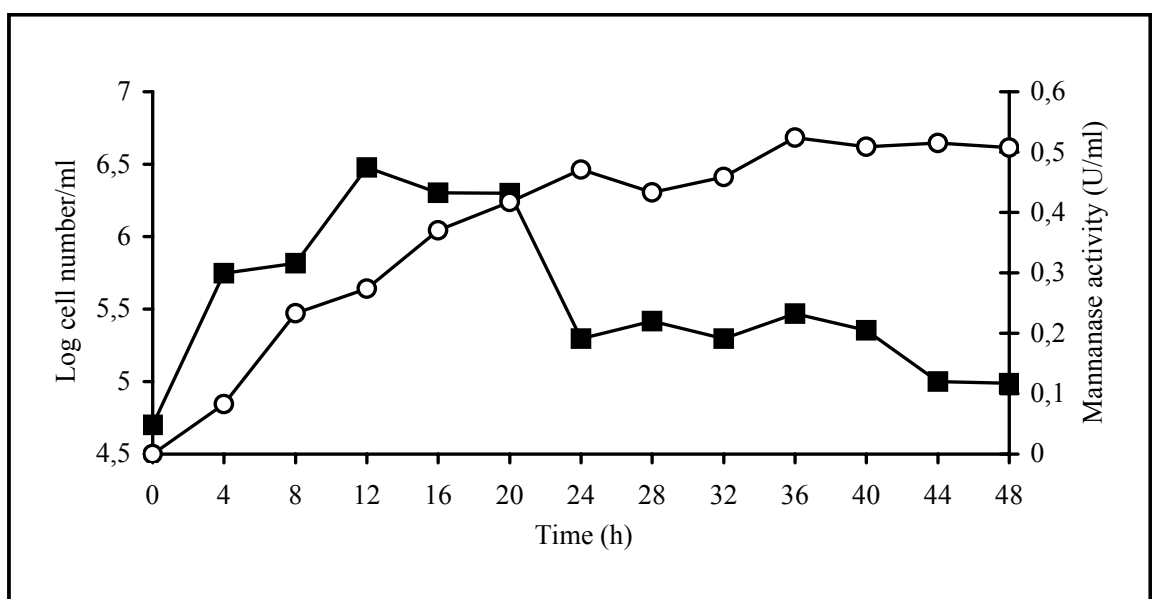

Figure 3. Growth curve and extracellular mannanase activity of Geobacillus stearothermophilus L-07. Strain L-07 was cultured at $60^{\circ} \mathrm{C}$ for 48 hours in the enzyme production medium. logarithmic viable cell number and -o- mannanase activity.

We studied the effect on the kind of carbon source on $\beta-1,4$ mannanase production. The bacteria produced active $\beta-1,4$ mannanase when they were grown in a kind of carbon source as medium (Table 3 ).

Table 3. Effect of carbon sources on the mannanase production. G. stearothermophilus L-07 was cultured at $60^{\circ} \mathrm{C}$ for 36 hours.

\begin{tabular}{clc}
\hline \hline No & Carbon sources & Relative activity (\%) \\
\hline 1 & None & $2 \pm 0.01$ \\
2 & Locust bean gum & $100 \pm 0.04$ \\
3 & Kolang kaling (endosperm from Arenga pinata) & $46 \pm 0.06$ \\
4 & Konjak & $13 \pm 0.05$ \\
5 & Palm kernel meal & $0 \pm 0.00$ \\
\hline
\end{tabular}


The enzyme activity in the medium containing locust bean gum was the highest, followed by that in kolang kaling, and konjak. No activity was observed in palm kernel meal. Thus, the best induction medium consisted of locust bean gum. It may be pointed out that the mannanase activity is preferably induced by polysaccharides containing mannose or galactose as monomeric unit, and the induction is strongly increased by heterogeneous polysaccharides containing mannose and galactose. Locust bean gum consists of $88 \%$ galactomannan (Whistler and BeMiller 1973). The composition may support the increase of mannanase production. So far, there was no accurate information on mannan composition in kolang kaling and palm kernel meal. However, they are found in palm seeds where galactomannans are major part of their dry weight.

Konjak mannan consist of 50-60\% glucomannan containing mannose and glucose. As comparison, Torrie et al. (1990) reported that the highest mannanase production was found from mold of Trichoderma harzianum E58 in the medium containing locust bean gum $(26.7 \mathrm{U} / \mathrm{mg}$ ), followed by konjak (glucomannan) $(7.5$ $\mathrm{U} / \mathrm{mg}$ ). Zakaria et al. (1998) showed that the enzyme activity from Flavobacterium sp. in the medium containing guar gum was the highest, followed by locust bean gum. In another research, Hossain et al. (1996), showed that Bacillus sp. KK01 in coconut meal resulted in mannanase activity of $0.04 \mathrm{U} / \mathrm{mg}$.

In non-mannan medium, $2 \%$ relative activity of mannanase was still found. In spite of non-mannan carbon source addition, the base medium might contain small amount of mannan from yeast extract. The mannan from yeast extract could induce mannanase production.

There was no mannanase activity in media containing mannan from palm kernel meal. When $G$. stearothermophilus L-07 was isolated by enrichment in liquid medium supplemented with $1 \%$ palm kernel meal as mannan source, the bacterium might survive due to synergism with other bacteria. Furthermore, G. stearothermophilus L-07 could not survive alone if it was cultured in palm kernel meal medium. According to Sumardi (2005), the palm kernel meal produced inhibiting substance after sterilization using an autoclave. Thus, G. stearothermophilus L-07 could neither grow nor produce $\beta$-mannanase.

The enzyme from G. stearothermophilus L-07 in the locust bean gum was further run on SDS-PAGE and analyzed by zymogram assay towards locust bean gum. Three bands were observed at molecular mass of approximately 85, 73, and 50 $\mathrm{kDa}$, respectively (Figure 4). The presence of three isozymes indicated that at least three mannanase encoded genes are present in L-07. Other G. stearothermophilus strains have been previously reported to produce mannanase with molecular mass of $76 \mathrm{kDa}$ and active at $70^{\circ} \mathrm{C}$ (Ethier et al. 1998). 
Isolation and characterization of mannanolytic thermophilic bacteria - Sumardi et al.

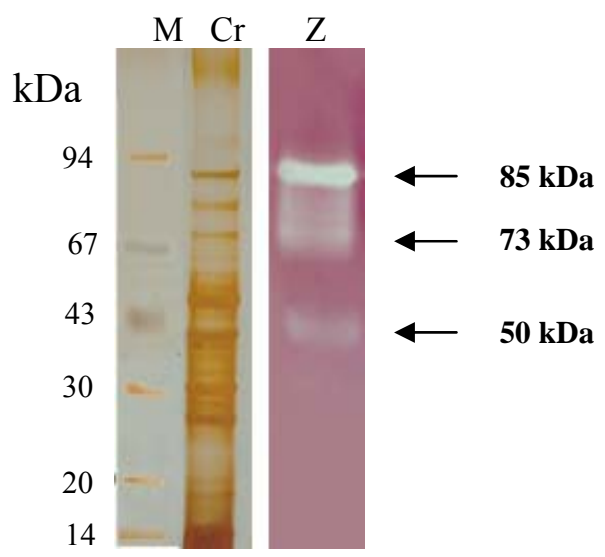

Figure 4. Zymogram of crude mannanase from G. stearothermophilus L-07. Lane M indicates the molecular size standard used in this study. Lane $\mathrm{Cr}$ indicates crude enzyme mannanase separated in SDS-PAGE. Lane $Z$ indicates bands of mannanase activity detected by zymogram.

\section{CONCLUSIONS}

We isolated G. stearothermophilus L-07 from palm shell, a solid waste of palm oil factory in Lampung. The bacterium produced extracellular $\beta-1,4-$ mannanase in locust bean gum medium, while $\beta$-mannosidase and $\alpha$-galactosidase were not detected. The optimum enzyme activity was observed after 36 hours of incubation at $60^{\circ} \mathrm{C}$. The mannanase comprised three active bands with molecular weight of 85,73 , and $50 \mathrm{kDa}$.

\section{ACKNOWLEDGEMENTS}

This research was financially supported by BPPS fellowship from National Education Department and Central Microbial Diversity of Bogor Agriculture University.

\section{REFERENCES}

Araujo, A \& O.P. Ward. 1990. Extracellular mannanases and galactanases from selected fungi. J. Indust. Microbiology. 6: 171-178

Aurora D D, Y. Lestari, \& A. Meryandini. 2003. Identifikasi bakteri penghasil mananase serta karakterisasi enzimnya. J. Mikrobiol. Indon. 8(1) : 31-33

Duffaud,G.D, C.M. McCutchen, P. Leduc, K.N. Parker, \& R.M. Kelly. 1997. Purification and characterization of extremely thermostable $\beta$-mannanase, $\beta$-mannosidase, and $\alpha$-galactosidase from 
the hyperthermophilic eubacterium Thermotoga neopalitana 5068. Appl. Environ. Microbiol. 63: $169-177$.

Euzeby. 2005. List of Prokaryotic Names with Standing in Nomenclature. Last full update September 14, 2005. URL: http://www.bacterio.net.

Ethier N, G. Talbot, \& J. Sygusch. 1998. Gene cloning, DNA sequencing, and expression of thermostable $\beta$-mannanase from Bacillus stearothermophilus. Appl. Environ. Microbiol. 64: 4428-4432.

Holt JG, NR Krieg, PHA Sneath, JT Staley, \& ST Williams. 1994. Bergey’s Manual of Determinative Bacteriology. Ninth edition. Baltimore : William and Wilkins.

Hossain, H.Z., J. Abe, \& S. Hizukuri. 1996. Multiple forms of $\beta$-mannanase from Bacillus sp. KK01. Enzyme Microb. Technol. 18 :95-98.

Marchesi, J.R.,T. Sato, A.J. Weightman, T.A. Martin, J.C. Fry, S.J. Hiom, D. Dymock, \& W.G. Wade. 1998. Design and evolution of useful bacterium spesific PCR primers that amplify genes coding for bacterial 16S-rRNA, J. Bacteriol. 64: 795-799.

Nazina T N, T P Tourova, A B Poltaraus, E V Novikova, A A Grigoryan, A E Ivanova, A M Lysenko, V V Petrunyaka, G A Osipov, S S Belyaev, \& M V Ivanov. 2001. Taxonomyc study of aerobic thermophilic bacilli : description of Geobacillus subterraneus gen. nov., sp. nov. and Geobacillus uzenensis sp. nov. from petroleum reservoirs and transfer of Bacillus stearothermophilus, Bacillus thermocatenulatus, Bacillus thermoleovorans, Bacillus kaustophilus, Bacillus thermoglucosidasius, and Bacillus thermodenitrificans to Geobacillus as the new combinations G. stearothermophilus, G. thermocatenulatus, G. thermoleovorans, G. kaustophilus, G. thermoglucosidasius, and G. thermodenitrificans. Int. J. Syst. Evol. Microbiol. 51: 433-446.

Ooi T \& D. Kikuchi. 1995. Purification and some properties of $\beta$-mannanase from Bacillus sp. World J. Microbiol. Biotechnol. 11:310-314.

Peer \& Watcher. 1993. Treecon: a software package for the construction and drawing of evolutionary trees. Comput. Applic. Biosci, 9: 177-182.

Politz O, M Krah, KK Thomsen, \& R Borriss. 2000. A highly thermostable endo-(1,4)- $\beta$-mannanase from the marine bacterium Rhodothermus marinus. Appl. Microbiol. Biotechnol. 53: 715-721.

Spindler, K.D. \& C. Rapp. 1997. Detection of chitin degrading enzymes on gels In: Chitin Handbook by eds. R.A.A. Muzzarelli \& M.G. Peter. European Chitin Society.

Sumardi. 2005. Isolasi, karakterisasi, dan produksi $\beta$-mananase ekstraseluler dari Geobacillus stearothermophilus L-07 [disertasi]. Bogor: Sekolah Pascasarjana, Institut Pertanian Bogor .

Torrie, J.P., D.J. Senior, \& J.N. Saddler. 1990. Production of $\beta$-mannanases by Trichoderma harzianum E58. Appl. Microbiol. Biotechnol. 34: 303-307.

Whistler, R.L. \& J.N. BeMiller. 1973. Industrial Gum: Polysaccharides and their derivates. Academic Press. New York.

Zakaria, M.M., M. Ashiuchi, S. Yamamoto, \& T. Yagi. 1998. Optimization for $\beta$-mannanase production of a psychrophilic bacterium, Flavobacterium sp. Biosci. Biotechnol. Biochem., 62: 655-660. 